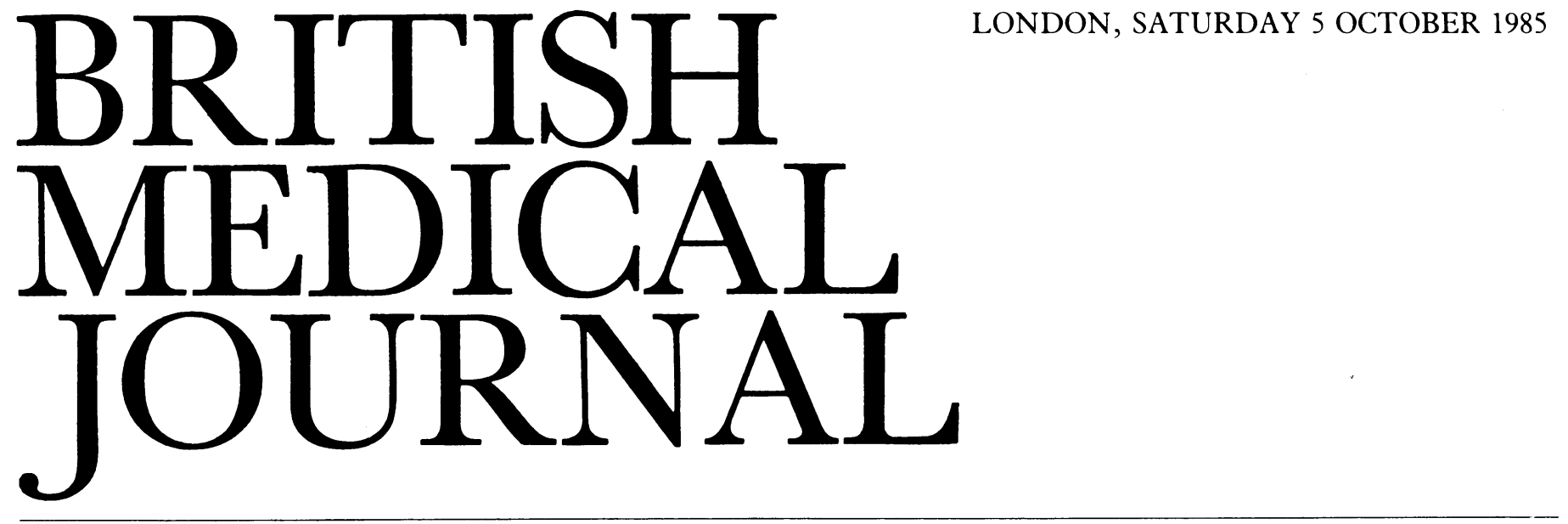

\title{
Management of multiple casualties with burns
}

Within the past 18 months disasters at the Abbeystead waterworks, Bradford City football stadium, and Manchester airport have forcefully reminded us of the problems posed by large numbers of people who have sustained burn injuries. Such disasters, though uncommon, are well documented, ${ }^{1.9}$ and these reports show that the number of survivors with burns presenting for treatment is rarely over 150 ; that the patients have often sustained other injuries including pulmonary inhalation injuries and fractures; and that most victims have a small percentage of body surface area burnt.

The recent Bradford football tragedy ( $\mathrm{p} 945$ ) occurred in a city possessing a plastic surgery unit of two consultants, one senior registrar, and supporting junior staff, with the nearby Yorkshire Regional Burn Centre at Wakefield conveniently placed promptly to receive the more extensively burnt patients. This fortunate chance provided immediate local skills for initial assessment of casualties reaching the accident and emergency department of Bradford Royal Infirmary soon after injury. Most survivors had not sustained extensive burns, but the medical staff were faced with many patients with burnt hands and scalps, for whom a policy of early excision of the burn (within five days of injury) was adopted; this was facilitated by the temporary transfer of nine plastic surgeons and trainees from plastic surgery units in Leeds, Manchester, and Newcastle.

When alerted to the imminent arrival of many patients with burns what should be the response of the local district general hospital and its accident and emergency department? A major accident should be declared to release facilities for the incoming casualties. The sorting, or triage, will be performed most effectively by a clinician experienced in the care of burns (in Britain usually a plastic surgeon)-for doctors without such experience frequently overestimate the proportion of the body surface burnt. Often, however, this will fall to the less experienced because there are only 115 consultant plastic surgeons in Britain (1:487 000 population). Anyone facing this task should appreciate that-unlike victims of other trauma-patients with burns will often appear surprisingly (and deceptively) well and lucid in the first four to six hours after injury. This is the period of maximal loss of intravascular fluid. Patients with all but minor burns should receive prompt fluid replacement to counteract the loss of protein rich fluid into the interstitial tissues.

(C) BRITISH MEDICAL JOURNAL 1985. All reproduction rights reserved.
Once an appropriate area within the hospital has been cleared to receive and assess the likely known number of casualties two senior clinicians (probably surgeons) should undertake triage. Junior staff can then be free to set up intravenous infusions, administer analgesia, obtain baseline blood samples and radiographs, arrange photographic documentation, and begin monitoring fluid balance. Patients should be weighed at reception unless their associated injuries preclude this. The extent of burn should be assessed in terms of the percentage of the body surface area using the palm of the patient's hand (fingers closed) as representing $1 \%$. For fluid replacement the percentage burn should exclude erythema alone; if it is included both fluid needs and the severity of the injury will be overestimated. Full thickness circumferential burns should be released by scalpel incision through the painless eschar to limit distal ischaemia. It is unnecessary to separate partial thickness and full thickness burn areas when calculating fluid requirements.

For victims of burn disasters triage must identify five important groups: those with minor burns in non-critical sites $(<10 \%$ body surface area in children, and $<20 \%$ body surface area in adults) of whatever depth, in whom loss of fluid should not be critical; those with minor areas of burn in critical sites-hands, face, and perineum; those with burns of $20-60 \%$ of body surface area, in whom hypovolaemia should be expected requiring intravenous fluid replacement and careful monitoring; those with extensive burns $(>60 \%$ body surface area) with a probable high mortality ${ }^{10}$; and those with minor burns but with lung damage from inhalation likely to develop or with associated major injuries such as fractures.

The first group may be managed as outpatients after wound dressings and antitetanus prophylaxis, with their follow up and redressing needs met in outpatient clinics. Patients in the second group should be admitted; facial burns may require early surgery to the eyelids to protect the eyes from exposure, and perineal burns are likely to require inpatient nursing. Burnt hands either are treated conservatively in plastic bags or gloves with the antibacterial silver sulphadiazine and with intensive physiotherapy ${ }^{11-14}$ or should undergo early excision of the wound and split thickness skin grafting. ${ }^{15-18}$ Full thickness burns of the hands benefit from early excision and grafting if the patient's general conditon permits. ${ }^{19}$ For deep dermal burns early surgery will reduce the length of hospital stay but does not seem to give better 
function than conservative treatment. ${ }^{15}{ }^{16}$ Early tangential excision may also have the short term disadvantage of cyst formation beneath the skin grafts. ${ }^{20}$ Once the hands have healed elastic pressure gloves worn for many months should control hypertrophic scarring.

In the third group if there are many casualties patients with $20-30 \%$ body surface area burns may be managed with oral fluids alone $(4 \mathrm{~g}$ sodium chloride and $1.5 \mathrm{~g}$ sodium bicarbonate in 1 litre of water, made palatable with orange squash) and remain in the district general hospital..$^{2122}$ Sorensen found that $80 \%$ of patients with burns of $<45 \%$ of body surface area may be managed with salt tablets washed down with fluids. ${ }^{23}$ Ideally patients with $30-60 \%$ body surface area burns and otherwise fit should be managed in burn units or centres because of their needs for intensive fluid replacement, monitoring, and adequate numbers of trained nurses (four trained nurses per patient per 24 hours).

Patients in the fourth group have a probable high mortality, and decisions to transfer any of them should be made at the district general hospital by a senior clinician from the nearest burn unit as soon as feasible. Patients whose main lesion is lung damage- - existing or anticipated (it may take several days to be a clinical problem)-should have their carboxyhaemoglobin concentration measured, ${ }^{24}$ be given oxygen, and considered for intubation and ventilation if their lung function deteriorates. Associated injuries should be dealt with by appropriate specialties.

For all but the minor burns supportive treatment should consist of reassurance (often overlooked), intravenous analgesia if needed, intravenous fluids, and wound dressings, usually with silver sulphadiazine cream. The initial pain will subside considerably within four hours of injury, and giving unnecessary opiates should be avoided. The adequacy of intravenous fluid replacement should be judged by the clinical response (pulse and respiration rates and state of peripheral skin circulation), serial measurements of peripheral venous packed cell volume, and hourly measurement of urine volume $(1 \mathrm{ml} / \mathrm{kg} /$ hour for children, and over 30 $\mathrm{ml} /$ hour in adults). Many patients tolerate maintenance oral fluids well (adults up to 2 litres/day); any vomiting may be related to opiates. The most popular intravenous resuscitation regimen in Britain uses colloid as plasma protein fraction and the Muir and Barclay formula developed for use with freeze dried plasma, ${ }^{25}$ the likely colloid need for 24 hours being assessed as $2.5 \mathrm{ml}$ colloid $/ \mathrm{kg}$ body weight $/ 1 \%$ body surface area burn. This estimate is only a guide, and patients given plasma protein fraction seem to need greater volumes than those given freeze dried plasma. ${ }^{26}$ If there are many casualties supplies of colloid may run out, but an alternative crystalloid regimen is offered by the Parkland formula- 4 $\mathrm{ml} / \mathrm{kg}$ body weight $/ 1 \%$ body surface area burn $/ 24$ hours, with no oral fluids in the first 24 hours. ${ }^{27}$ All fluid needs should be calculated from the time of burning, and regardless of the regimen used frequent clinical assessments of the patient are essential.

In the face of mass burn casualties the extensive facilities and necessary manpower for the early excision of extensive burns are not likely to be available-but while early excision of deep dermal and full thickness burns reduces hospital stay and hastens return to work, ${ }^{28-30}$ it may not influence ultimate mortality. ${ }^{28}$

RICHARD W GRIFFITHS

Consultant Plastic Surgeon,

Fulwood Hospital

Sheffield S10 3TD
1 Faxon NW. Management of the Cocoanut Grove burns at the Massachusetts General Hospital. The problems of the hospital administration. Ann Surg 1943;117:803.

Wells DB. The circus disaster and the Hartford Hospital. N Engl f Med 1945;232:613-6.

2 Wells DB. The circus disaster and the Hartford Hospital. N Engl f Med 1945;23 3 Blocker V, Blocker TG. The Texas city disaster. Am J Surg 1949;78:756-71.

Blocker V, Blocker TG. The Texas city disaster. Am Y Surg 1949;78:756-71.

Enyart JL, Miller DW. Treatment of burns resulting from disaster. FAMA 1955;158:95-100. Schenk WG, Stephens JG, Burke J, Hale HW, Eagle JF, Stewart JD. Treatment of mass civilian burn casualties. Care of Cleveland Hill School fire victims. Arch Surg 1955;71:196-201.

6 Callahan JJ, Segraves JE. Treatment of fire victims: Lady of the Angel School disaster. Am 7 Surg 1960;99:814-6

7 Hart RJ, Lee JO, Boyles DJ, Batey NR. The Summerland disaster. Br Med J 1975;i:256-9.

8 Carswell JW, Rambo WA. A fire at Nakivubo, Kampala. 1. Management of the burned patients. Burns Incl Therm Inj 1976;2:178-83.

9 Allister C, Hamilton GM. Cardowan coal mine explosion: experience of a mass burns incident. $\mathrm{Br}$ Med f 1983;287:403-5.

10 Bull JP. Revised analysis of mortality due to burns. Lancet 1971;ii: 1133-4.

11 Slater RM, Hughes NC. A simplified method of treating burns of the hands. Br $\mathrm{f}$ Plast Surg 1971;24:296-300

12 Bailey BN, Desai SN. An approach to the treatment of hand burns. Injury 1973;4:335-40.

13 Sykes PJ, Bailey BN. Treatment of hand burns with occlusive bags: a comparison of 3 methods. Burns Incl Therm Inj 1976;2:162-8.

14 Frandsen PA, Overgaard-Neilsen H, Sommer J. Treatment of second-degree burns of the hand: a comparison of occlusive dressings and gloves. Burns Incl Therm Inj 1977;4:20-2

15 Salisbury RE, Wright P. Evaluation of early excision of dorsal burns of the hand. Plast Reconstr Surg 1982;69:670-5

16 Goodwin CW, Maguire MS, McManus WF, Pruitt BA. Prospective study of burn wound excision of the hands. F Trauma 1983:23:510-7.

17 Madden JW, Enna CD. The management of acute thermal injuries to the upper extremity. $f$ Hand Surg 1983;8:785-8.

18 Wang X-W, Sun Y-H, Zhang Z-M, Davies JWL. Tangential excision of eschar for deep burns of the hand: analysis of 156 patients collected over 10 vears. Burms Incl Therm Inj 1984:11:92-8.

9 Hunt JL, Sato RM. Early excision of full-thickness hand and digit burns: factors affecting morbiditv. F Trauma 1982;22:414-9.

20 Tandon $\mathrm{SN}$, Sutherland $\mathrm{AB}$. Some problems following tangential excision and skin grafting in dermal burns. Burns Incl Therm Inj 1977;3:96-9.

21 Phillips AW. Burn therapy: $\mathrm{V}$. Disaster management-to treat or not to treat? Who should receive intravenous fluids? Ann Surg 1968:168:986-96.

22 Artz CP, Moncrief JA. The treatment of hurts. 2nd ed. Philadelphia:W B Saunders Co, 1969.

3 Sorensen B. Management of hurns occurring as mass casualties after nuclear explosion. Burms Incl Therm Inj 1979;6:33-6

24 Clark CJ, Campbell D, Reid WH. Blood carboxyhaemoglobin and cyanide levels in fire survivors. Lancet $1981 ; 1: 1332-5$.

25 Muir IFK, Barclay TL. Burns and their treatment. London: Lloyd-Luke, 1962.

26 Watson JS, Walker CC, Sanders R. A comparison between dried plasma and plasma protein fraction in the resuscitation of burn patients. Burns Incl Therm Inj 1977;3:108-11.

Baxter CR, Shires GI'. Physiological response to crystalloid resuscitation of severe burns. Ann NY Acad Si 1968;150:874-94.

28 Curreri PW, Luterman A, Braun DW, Shires GT. Burn injury: analysis of survival and hospitalization time for 937 patients. Ann Surg 1980;192:472-8.

29 Gray DT, Pine RW, Harnar TJ, Marvin JA, Engrav LH, Heimbach DM. Early surgical excision versus conventional therapy in patients with 20 to 40 percent burns: a comparative study. $A m \mathcal{F}$ Surg 1982;144:76-80

30 Engrav LH, Heimbach DM, Reus JL, Harnar TL, Marvin JA. Early excision and grafting vs nonoperative treatment of burns of indeterminate depth: a randomized prospective study. 7 Trauma 1983;23:1001-4.

\section{The Debendox saga}

In 1956 a combined preparation of doxylamine, dicyclomine, and pyridoxine was marketed in the United States under the trade name Bendectin. It was widely used to treat nausea and vomiting early in pregnancy, and was marketed in Britain in 1958 as Debendox. Since that time, particularly in the United States, there have been anecdotal reports of women who had consumed Debendox (or Bendectin) and had later given birth to a malformed infant. Several studies, however, have failed to show any evidence of a connection between Debendox and congenital abnormalities. Nevertheless, the production of the drug was halted in 1983, and in the United States the manufacturers settled out of court the legal case in which claimants alleged that the drug had damaged infants in utero. Apparently to continue to defend the case would have cost more than the settlement. Probably 33 million pregnant women were exposed to Debendox. ${ }^{1}$ How was it that the scientific evidence was not conclusive?

When confronted by an infant with a congenital abnormality whose mother took Debendox in pregnancy, especially before the ninth week, the two events may easily be linked in the minds of the parents and others. Certainly this approach has been almost too appealing for many lay commentators. The scientific approach, however, should be very different, since most doctors (and many lay people) are

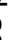

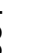
(n) (n) (n) 